\title{
Genitalia self-mutilation commanded by hallucinations: a psychointensive case of Klingsor syndrome
}

\author{
Sasmith Menakuru, ${ }^{1,2}$ Mir Inzamam Alii, ${ }^{3}$ Kashyap Karasala ${ }^{4}$
}

'Department of Internal Medicine, Narayana Medical College and Hospital, Nellore, India

${ }^{2}$ Mount Sinai Health System, New York, USA

${ }^{3}$ RAK College Of Medical Sciences, Ras-al-Khaimah Medical and Health Sciences University, UAE

${ }^{4}$ Department of Surgery, Narayana Medical College and Hospital, Nellore, India

Correspondence to Dr. Sasmith Menakuru sasmithm@gmail.com

Accepted 3 September 2018

\section{DESCRIPTION}

One of the world's rarest cases recorded up to date stands a case of hallucination influenced genitalia self-mutilation (GSM). There are just 13 cases recorded on PubMed till date. What and who is Klingsor? It was derived from the name of a character in Parsifal (a German opera) who had engaged in the act of self-castration for gaining entry into the prestige brotherhood of the Knights of the Holy Grail. In one of the first recorded cases in 1990, the author argued that the term 'Klingsor' be applied to all cases of GSM to patients of psychotic illness and not just religious conflicts. ${ }^{1}$ Some literatures call this syndrome as Skoptic syndrome.

Various surveys done by psychologists found psychosis beneath the cases of men carrying out autocastration. One of the most famous cases documented of Thomas Corbett, the man behind the assassination of John Wilkes Booth and Abraham Lincoln is thought to had done so out of madness.

In a recent article, a systematic review of 173 cases of men who engaged in GSM published in the past 115 years revealed that there was some underlying form of psychopathology that elevated or encouraged GSM. It also found out that nearly half of these cases had psychosis, and they were more likely to carry out GSM during the first episode or early stages of psychosis. Besideshallucinations, delusions, need for atonement and suicidal behaviour have been reported among various other causes in such individuals with psychosis.

As per the available literature, three most commonly affected organs involved in the self-mutilation are the skin, eyes and external genitalia. ${ }^{2}$

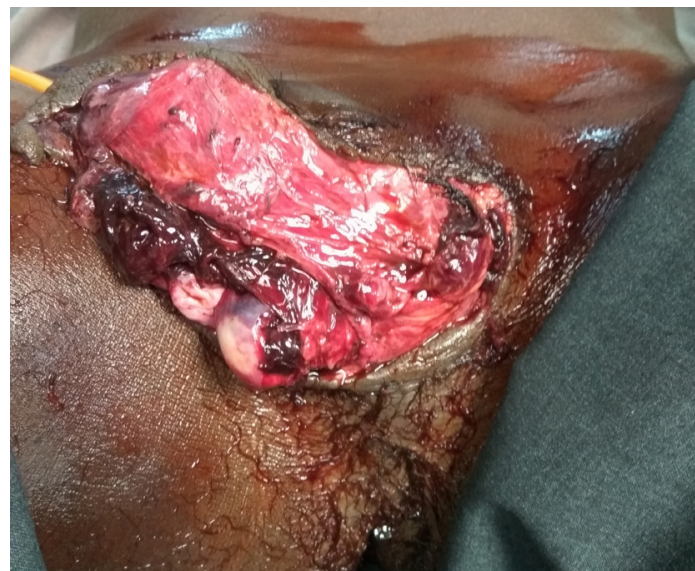

Figure 1 U-shaped lacerated wound of the scrotum.

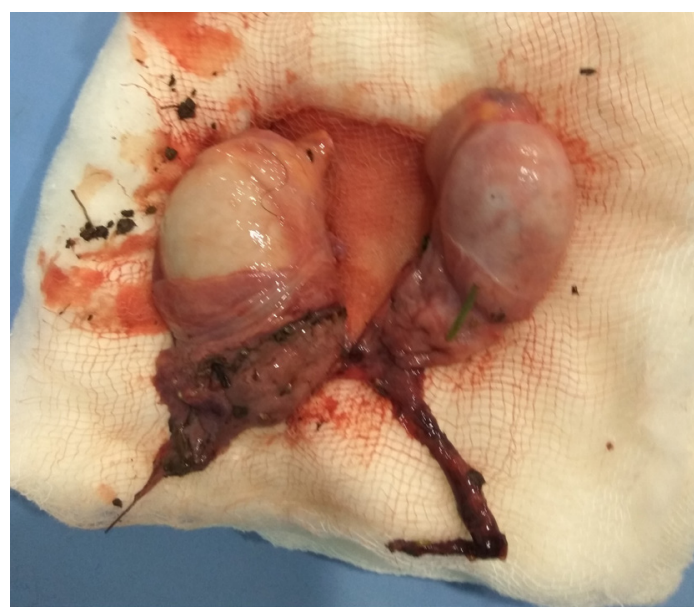

Figure 2 The testis recovered from the site.

Single adult men in the age group 20-29 years, victims or committers of sexual crimes or with homosexual tendencies are also prone to these acts, sometimes even normal non-psychiatric patients. ${ }^{3}$ Here, we report acase of a man with an undiagnosed psychiatric history who indulged in self-mutilation of his genitalia as a way to expiate his sins after having a vision of God commanding him to do so. Besides being a rare surgical emergency, there is inadequate data on timely and appropriate management to ensure structural, functional and cosmetic integrity.

A 35-year-old unmarried man, an agricultural worker, was brought to the emergency department after deliberate slicing of his external genitalia with a sickle while working in his fields. $\mathrm{He}$ was conscious but sluggish in responding to verbal commands immediately. His pulse rate and blood pressure recordings were normal. Local examination of external genitalia revealed that the scrotum was cut in a 'U'-shaped manner and both testes were missing. The wound was filled with a blood clot (figure 1). The relatives who brought the patient got the missing testis in a separate plastic bag (figure 2). On repeated questioning, the patient said that he heard a Goddess asking him to 'cut off' his penis while working in the fields. So, he sliced his penis and cut out his testicles with a sickle.

After resuscitation and the relevant investigations, he was taken to the operation theatre where the wound underwent debridement. After 3 days, delayed primary suturing was done (figure 3). In view of his abnormal mental status, he was referred to a psychiatrist, confirmed as a case of 


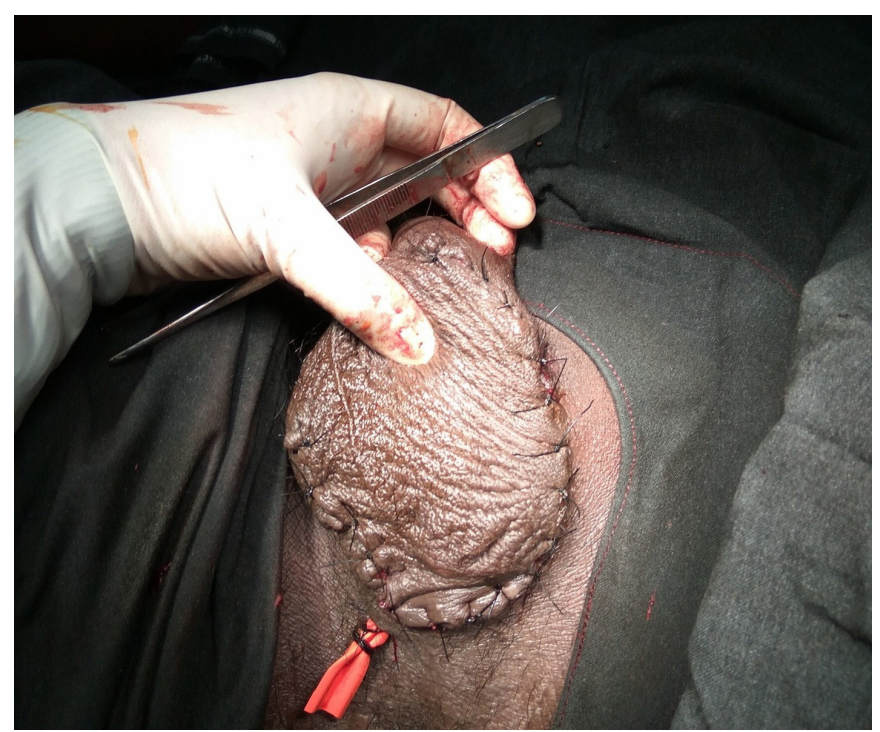

Figure 3 Sutured scrotum with drain.

schizophrenia. He was recommended a monthly follow-up to check for the high risk of developing Fournier's gangrene due to the occupation as a farmer and/or mummification due to his laceration. Other consequences that may arise are development of a urinary fistulae or strictures, mummification of the reimplanted penis and sensory dysfunction.

GSM is most commonly seen in patients with schizophrenia who present with altered pain impression and its manifestation might be related to such inflictions. Occasionally it may be seen in a transvestite (cross-dresser); the transvestite, however, usually manages to do the castration medically. A third group because of complex religious or cultural beliefs proceeds with self-castration. It is a heterogeneous form of self-injury that can range from superficial genital lacerations, amputation or castration to a combination of all these.

As recovery is a non-static process and due to the evolving reaction of the patient to the injury, besides doing a timely initial injury and surgical management, psychiatric interventions are necessary to help such patients recover.

\section{Learning points}

- Victimised patients of sexual abuse or those who indulge in abusive activities are more likely to suffer from Klingsor syndrome with underlying schizophrenia.

- Attempts at reimplantation must be carried out for the least achievement of cosmetic and psychosocial benefits.

- A multifaceted approach involving psychiatric and psychotherapeutic interventions is necessary as an initial management in such patients.

Contributors KK and SM saw the case. SM discussed the case with MI and they decided to write up a case report. The manuscript was equally written by all authors. Pictures were edited by MI. All authors contributed equally.

Funding The authors have not declared a specific grant for this research from any funding agency in the public, commercial or not-for-profit sectors.

Competing interests None declared.

Patient consent Next of kin consent obtained.

Provenance and peer review Not commissioned; externally peer reviewed.

\section{REFERENCES}

1 Schweitzer I. Genital self-amputation and the Klingsor syndrome. Aust N Z J Psychiatry 1990;24:566-9.

2 Ames D. Autocastration and biblical delusions in schizophrenia. Br J Psychiatry 1987; 150:347.

3 Martin T, Gattaz WF. Psychiatric aspects of male genital self-mutilation. Psychopathology 1991;24:170-8.

Copyright 2018 BMJ Publishing Group. All rights reserved. For permission to reuse any of this content visit

http://group.bmj.com/group/rights-licensing/permissions.

BMJ Case Report Fellows may re-use this article for personal use and teaching without any further permission.

Become a Fellow of BMJ Case Reports today and you can:

- Submit as many cases as you like

- Enjoy fast sympathetic peer review and rapid publication of accepted articles

- Access all the published articles

- Re-use any of the published material for personal use and teaching without further permission

For information on Institutional Fellowships contact consortiasales@bmjgroup.com

Visit casereports.bmj.com for more articles like this and to become a Fellow 